\title{
Primary Pulmonary Fibrosarcoma With Bone Metastasis: a Successful Treatment With Post-Operation Adjuvant Chemotherapy
}

\author{
Amirataollah Hiradfar ${ }^{1, *} ;$ Tala Pourlak $^{2} ;$ Davoud Badebarin $^{3}$

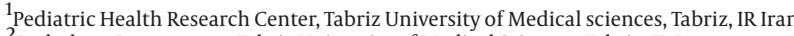 \\ ${ }_{2}^{2}$ Pathology Department, Tabriz University of Medical Sciences, Tabriz, IR Iran \\ ${ }^{3}$ Pediatric Surgery Department, Tabriz University of Medical Sciences, Tabriz, IR Iran \\ ${ }^{*}$ Corresponding author: Amirataollah Hiradfar, Pediatric Department, Tabriz University of Medical sciences, Tabriz, IR Iran. Tel: +98-9143135235, Fax: +98-4135262250, \\ E-mail: hiradfara@gmail.com
}

Received: August 10, 2014; Accepted: November 5, 2014

\begin{abstract}
Introduction: Pulmonary fibrosarcoma has been an extremely rare tumor in children. Wide surgical resection of infantile fibrosarcoma would be the treatment of choice.

Case Presentation: Post-operative chemotherapy has shown the benefit in the cases of residual disease after initial surgery and metastatic disease in the literature. We have presented the case of a 70-days old male child with primary infantile fibrosarcoma of the left lung and distant metastasis of skull.

Conclusions: The aim of this publication was to highlight the role of adjuvant chemotherapy to improve outcome of infantile fibrosarcoma with residual tumor and / or metastatic disease.
\end{abstract}

Keywords: Fibrosarcoma; Chemotherapy; Lung; Infantile

\section{Introduction}

Fibrosarcoma has shown as heterogenous group of malignant mesenchymal origin tumor that has classified as non-rhabdomyosarcoma Soft Tissue Sarcoma (NRSTS) (15). Fibrosarcoma has accounted for about $5 \%$ of pediatric NRSTS and for approximately $25 \%$ to $30 \%$ of soft tissue malignancies in children younger than 1 year $(6,7)$.

According to the POG staging system for NRSTS, a fibrosarcoma has considered infantile fibrosarcoma (IFS) if it has occurred in 4 years old children or younger (8). Because fibrosarcoma in young children was considerably less aggressive and most curable than the elder children, it has labeled "infantile fibrosarcoma" (IFS) (1-6).

Fibrosarcoma most commonly has presented at the extremities, trunk, and head/neck (9). Primary pulmonary fibrosarcoma was extremely rare lung neoplasm that has accounted for about $12 \%$ of all pulmonary tumors in infants and young children (10). Fibrosarcoma of the lung could arise from the trachea, bronchus, pulmonary parenchyma or pulmonary artery (10).

Pulmonary fibrosarcoma has diagnosed, following ruling out more common causes of lung masses, such as bronchogenic cyst, adenomatoid malfunction, and sequestration of the lung through clinical findings and imaging studies.

\section{Case Presentation}

Our case was a 70-days old male child that has presented with respiratory distress and cyanosis following breastfeeding. Physical examination was normal except the tachypnea, subcostal retraction.

The infant's arterial oxygen saturation was $92 \%$ at room air. The patient has admitted with initial diagnosis of pneumonia and subsequently an antibiotic therapy has initiated. Initial laboratory investigations were normal (Table 1).

A chest radiography has shown an opacity in the lower part of the left lung. A computerized tomography (CT) of the thorax has revealed a well-defined heterogeneously enhancing mass measuring $45 \mathrm{~mm} \times 40 \mathrm{~mm}$ in the lower lobe of the left lung (Figure $1 \mathrm{~A}$ and $1 \mathrm{~B}$ ). There was no pleural effusion. Differential diagnoses has proposed by radiological service has included pulmonary sequestration and congenital adenomatoid malformation. The exploration has revealed a mass measuring $50 \mathrm{~mm} \times$ $40 \mathrm{~mm} \times 20 \mathrm{~mm}$, involving the lower lobe of the left lung, having a solid appearance. The mass has resected via the left lower lobectomy. There was no spread to the chest wall. After installing chest tube, infant has supported through mechanical ventilation during the post-operative period and has discharged from Pediatric Intensive Care Unit after 4 days with no further problems with respiratory distress.

Copyright (C) 2015, Iranian Journal of Cancer Prevention. This is an open-access article distributed under the terms of the Creative Commons Attribution-Non Commercial 4.0 International License (http://creativecommons.org/licenses/by-nc/4.0/) which permits copy and redistribute the material just in noncommercial usages, provided the original work is properly cited. 
Hiradfar A et al.

\begin{tabular}{lcc}
\hline Table 1. Laboratory Findings at Diagnosis & & \\
\hline & Patient & Reference Value \\
\hline Erythrocyte count & $4.33 \times 10^{6} / \mu \mathrm{L}$ & $(12-6-6.2)$ \\
\hline Hemoglobin & $11.8 \mathrm{~g} / \mathrm{dL}$ & $(36-50)$ \\
\hline Hematocrit & $33.3 \%$ & $(6.1-10.3)$ \\
White blood cell (WBC) & $6.8 \times 10^{3} / \mu \mathrm{L}$ & $(0-5)$ \\
\hline C-reactive protein (CRP) & $2 \mathrm{mg} / \mathrm{dL}$ & $(10-50)$ \\
\hline Urea & $21 \mathrm{mg} / \mathrm{dL}$ & $(0.3-1)$ \\
\hline Creatinine & $0.4 \mathrm{mg} / \mathrm{dL}$ & $(1.05-1.37)$ \\
Calcium (ionized) & $1.08 \mathrm{mmol} / \mathrm{L}$ & $(50-110)$ \\
\hline Blood glucose & $72 \mathrm{mg} / \mathrm{dL}$ & $(5-40)$ \\
\hline SGPT & $20 \mathrm{IU} / \mathrm{L}$ & $(5-40)$ \\
\hline SGOT & $32 \mathrm{IU} / \mathrm{L}$ & \\
\hline
\end{tabular}
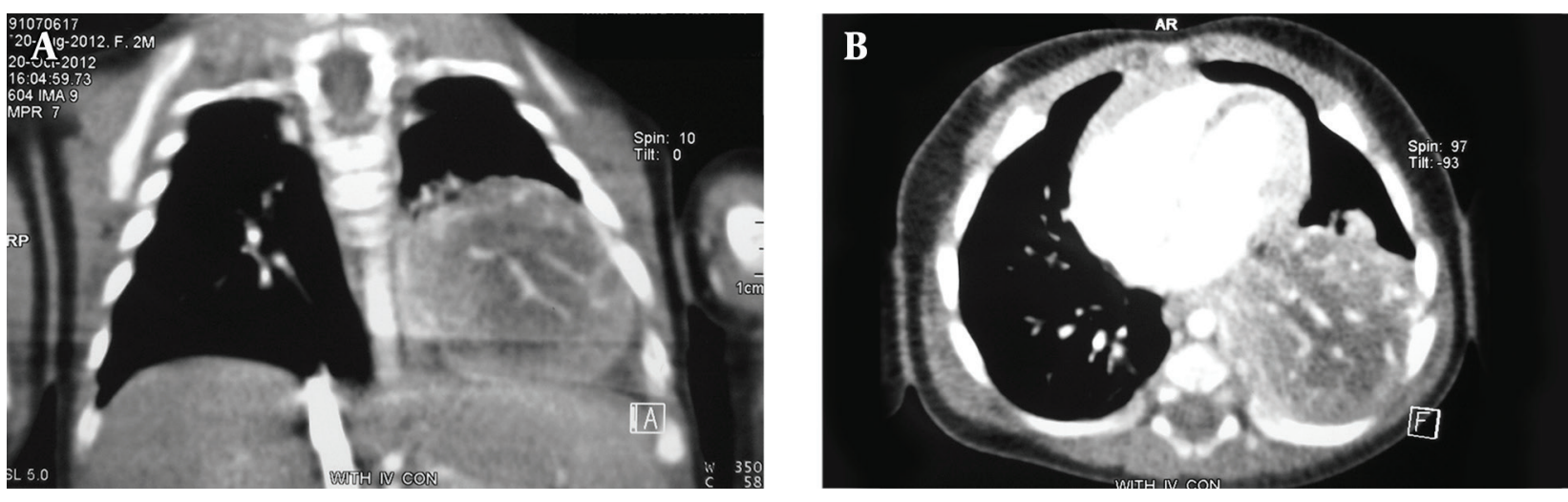

Figure 1. A Large Lung Mass of Left Lower Lobe

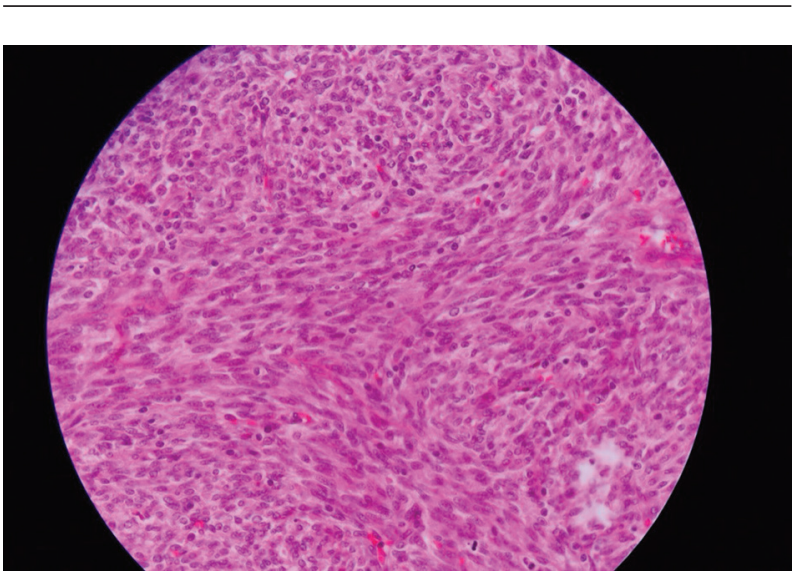

Figure 2. Proliferation of Neoplastic Cell
Macroscopic examination has consisted of a lung lob measuring $50 \times 40 \times 20 \mathrm{~mm}$. Cross-section shown a gray-white well circumscribed soft to firm mass with irregular brown border. Histological examination of tissue sections has revealed proliferation of neoplastic cells in lung tissue (Figure 2).

There was atypical proliferation of spindled to fusiform cells have arranged in interlacing long fascicules. The neoplastic cells has shown little pleomorphism, scanty cytoplasm with indistinct cell borders and have separated by interwoven collagen fibers and have arranged in a parallel fashion. Occasioned mitotic were were present (1-2 HPF). The tumor has contained areas of hemorrhage and necrosis.

There was prominent lymphoid infiltration throughout the neoplasm. Resected margin and pleural surface were free. The resected tissues have also subjected to immunohistochemistry. The tumor cells were 
positive for Vimentin but non-reactive for cytokeratin, S-100 protein, a smooth muscle actin, and desmin. The pathological evaluation has revealed the diagnosis of primary pulmonary Fibrosarcoma.

Metastatic workups including radionuclide bone scan and skull CT examinations have taken after initial surgery. Increased skeletal has up taken of the skull bones have detected by (Tc)-99m-labeled methylene diphosphonate (MDP) (Figure 3A). Skull CT examinations have revealed bone lesions without brain parenchymal disease (Figure 3B). There was a residual tumor measuring $5 \times 7 \mathrm{~mm}$ dimensions on subsequent chest CT scan after surgery.

Post-operation adjuvant chemotherapy has planned to treat residual disease and distant bone metastasis. Chemotherapy regimen has included (VA: vincristine $0.025 \mathrm{mg} / \mathrm{kg}$ day 1; Actinomycin D $7.5 \mu \mathrm{g} / \mathrm{kg}$ days 1-5). He has received 12 cycles of VA regimen supported with granulocyte colony-stimulating factor (G-CSF). The infant has routinely assessed for liver, renal, cardiac and pulmonary functions through physical examination and laboratory investigations during the chemotherapy treatment.

After completing 12 cycles of VA regimen, there was no any sign of residual tumor on CT of the thorax. During the follow-up, skeletal Tc-99m MDP uptake was normal after completing the chemotherapy treatment.

FDG-active metastatic lesion was normal on FDG-PET imaging after 12 cycles of VA regimen. He has grown up as a 21-months old boy without any sign of recurrence by radiological and physical examinations and has been off therapy since 18 months. During this time, infant has enjoyed normal growth and development.

\section{Discussion}

IFS has more seen among infants younger than two years of age (11). According to existing information, IFS has rather affected limbs (especially the distal part), trunk (including shoulder and pelvic girdles) and head and neck (12-17).

In histological terms, IFS was similar to the adult type, but clinical presentations of the disease in these two age groups had obvious differences $(18,19)$. Furthermore, in genetic terms, IFS has characterized by chromosomal translocation $(15,18)$ (P13, q25), which has led to ETV6-NTRK3 fusion gene $(20,21)$. Local recurrence was a common problem in IFS, while distant metastases were rare. Prognosis and long-term survival has much better in IFS compared to adults $(1,6,18,19)$.

The main treatment of fibrosarcoma has involved complete surgical resection of tumor (11-15, 22-25) Possibility of complete resection of the tumor has increased chances of recovery and non-recurrence of disease. However, it was not always possible to perform complete resection, like masses in head and neck, or metastatic development of primary disease when using chemotherapy, before or after biopsy or tumor resection, which led increasing recovery and survival rates (22-29).

Currently, there were several reports in the literature on the effective role of adjuvant chemotherapy after tumor resection in the treatment of infantile fibrosarcoma (Table 2).

Mayo clinic has reported by Soule et al. (13) on 40 patients with IFS, recurrence of disease was $37.5 \%$. In this report, only surgery and radiotherapy have used in treatment of the patients.
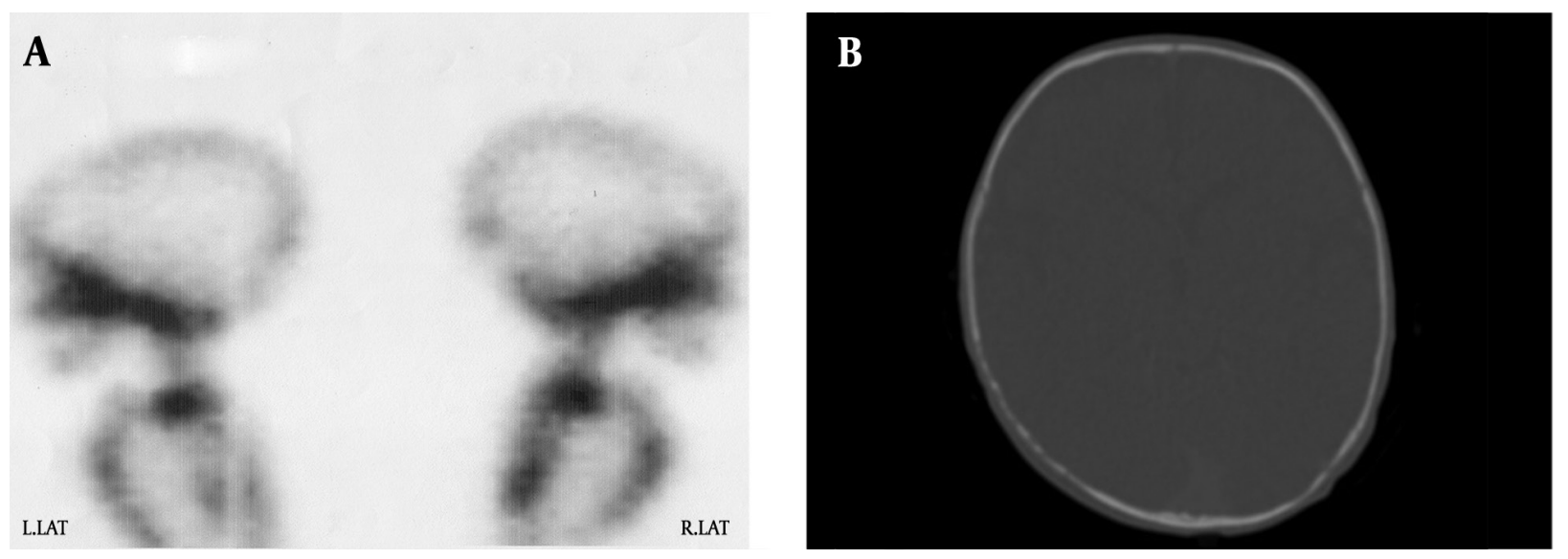

Figure 3. Skull bone metastasis 
Table 2. Therapeutic Approach and Outcome of Infantile Fibrosarcoma in the Literature ${ }^{a}$

\begin{tabular}{|c|c|c|c|c|c|c|c|c|c|c|c|}
\hline 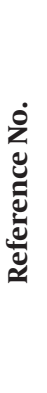 & 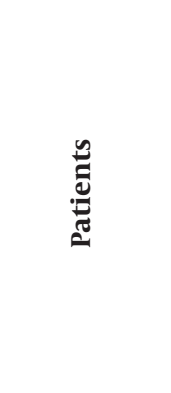 & 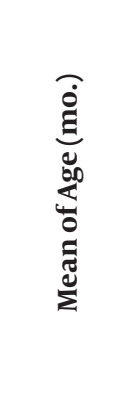 & 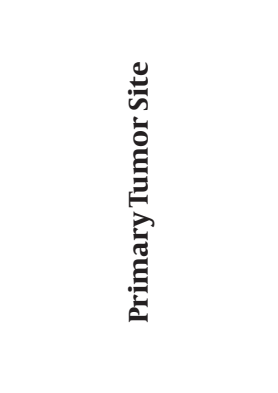 & 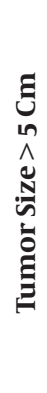 & 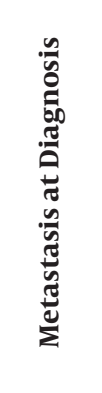 & 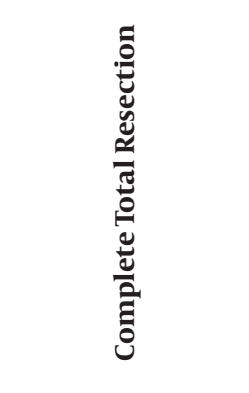 & 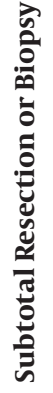 & 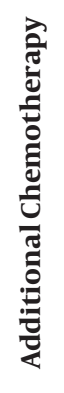 & 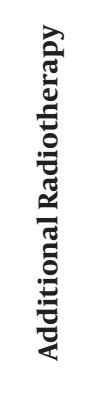 & 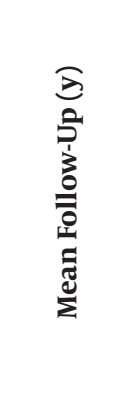 & 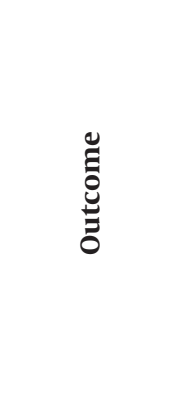 \\
\hline 22 & $\mathrm{M}=7, \mathrm{~F}=6$ & $9.3 \pm 8.8$ & $\begin{array}{c}\mathrm{L}=7, \mathrm{~T}=4, \text { face }=1, \\
\mathrm{R}-\mathrm{P}=1\end{array}$ & 12 & $\begin{array}{l}1 \mathrm{R}-\mathrm{P} \\
\text { tumor }\end{array}$ & 10 & 3 & 4 & $\begin{array}{l}1 \mathrm{R}-\mathrm{P} \\
\text { tumor }\end{array}$ & $2.9 \pm 2.4$ & $\begin{array}{c}C=10, R=2, \\
D=1\end{array}$ \\
\hline 24 & $\mathrm{M}=35, \mathrm{~F}=21$ & 2.6 & $\begin{array}{c}\mathrm{L}=37, \mathrm{~T}=14, \mathrm{H} \text { and } \\
\mathrm{N}=5\end{array}$ & 35 & 2 & 25 & 33 & 34 & 1 & 4.9 & $\begin{array}{c}C=39, R=10, \\
D=5\end{array}$ \\
\hline 28 & $M=9, F=2$ & - & $\begin{array}{c}\mathrm{L}=6, \mathrm{~T}=2, \mathrm{H} \text { and } \\
\mathrm{N}=3\end{array}$ & 8 & 2 & 1 & 10 & 10 & none & $5.5 \pm 4.8$ & $\begin{array}{c}C=8, R=3 \\
D=3\end{array}$ \\
\hline 23 & $\mathrm{M}=7, \mathrm{~F}=4$ & $\begin{array}{l}\text { Birth to } 12 \\
\text { mo. }\end{array}$ & $\begin{array}{c}\mathrm{L}=3, \mathrm{~T}=6, \mathrm{H} \text { and } \mathrm{N}= \\
1, \mathrm{R}-\mathrm{P}=1\end{array}$ & $?$ & none & 3 & 8 & 8 & 1 & 6.5 & $\begin{array}{c}C=10, R=1 \\
D=1\end{array}$ \\
\hline 13 & $M=17, F=23$ & $\begin{array}{c}\text { Birth to } \\
16 \mathrm{y}\end{array}$ & $\begin{array}{c}\mathrm{L}=33, \mathrm{~T}=5, \mathrm{H} \text { and } \\
\mathrm{N}=2\end{array}$ & 13 & 7 & 23 Amputation (4) & 9 & one & 5 & $12.2 \pm 11.9$ & $\begin{array}{c}C=21, R=15, \\
D=8\end{array}$ \\
\hline
\end{tabular}

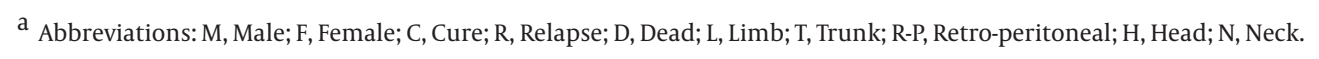

Loh et al. (23) has reported, based on Dana Farber Cancer Institute results, use of adjuvant chemotherapy has increased cure rate in infants with fibrosarcoma.

Orbach et al. (24) has reported a retrospective analytical study on the outcome of IFS treatment in Europe between 1979 and 2005, of the 56 patients, 34 (60.7\%) have received adjuvant chemotherapy, and recurrence rate was $18 \%$. Inthis analytical study, use of chemotherapy has improved outcome of the patients.

In the other reports, use of adjuvant chemotherapy has also led to increased cure rate in infants with fibrosarcoma (25-30).

In Mayo clinic report, of the 27 patients have operated, 4 underwent amputation (13). As highlighted by Orbach, (24) and Kupeli (28) reduced amputation rate with preoperative chemotherapy, have followed by delayed surgery clearly has shown positive role of chemotherapy.

Few reports have been published on primary pulmonary fibrosarcoma (31-34). In most of these reports, surgery was the first line of treatment, and in cases where complete tumor resection was not possible or in pres- ence of distant metastasis, use of adjuvant chemotherapy has increased long-term survival of patients.

In the most published reports, chemotherapy regimens have included vincristine and actinomycin D, with or without cyclophosphamide (22-25). Chemotherapy regimens that have included Doxorubicin, Ifosfamide, and Etoposide have also been used, although these drugs might be more toxic, particularly to young children. There was no systematically comparison between various chemotherapy protocols in treatment of IFS.

Savas et al. (31) has reported a 12-year-old boy with primary bronchopulmonaryfibrosarcoma. He has misdiagnosed a having asthma. Successful treatment has achieved with surgical resection of the tumor followed by adjuvant chemotherapy and radiotherapy.

Picard et al. (32), has reported an eight-year-old boy with primary endobronchialfibrosarcoma. He has received preoperative chemotherapy, followed by delayed complete tumor resection. In the two-year follow-up, no sign of recurrence has observed.

Sahin et al. (33) has reported a one-day-old male in- 
fant with congenital pulmonary fibrosarcoma. He has presented with respiratory distress and radiographic opacity in the middle part of the right lung. He has achieved successful treatment by surgery.

Pettinato et al. (34) has reported 5 cases of bronchopulmonaryfibrosarcoma in newborns and children up to 11 years of age at diagnosis. After complete tumor resection in 4 cases, and in 4-9 years follow-up, no sign of recurrence has observed.

Primary pulmonary fibrosarcoma would be an extremely rare tumor of lung in the pediatric age group. In radiological terms, it was in the form of a fine mass, or lobule, and could not be differentiated from other more common pulmonary masses. The main treatment was surgery with complete resection of tumor. Use of post-operation adjuvant chemotherapy in the cases of infantile fibrosarcoma could improve longterm survival especially in presence of residual tumor after surgery and metastatic disease.

\section{Conflict of Interest}

The authors made no disclosures.

\section{References}

1. Coffin CM, Dehner LP. Soft Tissue Tumors in First Year of Life: A Report of 190 Cases. Fetal Pediatric Pathol. 1990;10(4):509-26.

2. Hayani A, Mahoney DJ, Hawkins HK, Steuber CP, Hurwitz R, Fernbach DJ. Soft-tissue sarcomas other than rhabdomyosarcoma in children. Med Pediatr Oncol. 1992;20(2):114-8.

3. Coffin CM, Jaszcz W, O'Shea PA, Dehner LP. So-called congenitalinfantile fibrosarcoma: does it exist and what is it? Pediatr Pathol. 1994;14(1):133-50.

4. Cecchetto G, Carli M, Alaggio R, Dall'Igna P, Bisogno G, Scarzello $\mathrm{G}$, et al. Fibrosarcoma in pediatric patients: results of the Italian Cooperative Group studies (1979-1995). J Surg Oncol. 2001;78(4):225-31.

5. Orbach D, Rey A, Oberlin O, Sanchez de Toledo J, Terrier-Lacombe MJ, van Unnik A, et al. Soft tissue sarcoma or malignant mesenchymal tumors in the first year of life: experience of the International Society of Pediatric Oncology (SIOP) Malignant Mesenchymal Tumor Committee. J Clin Oncol. 2005;23(19):4363-71.

6. Koscielniak E, Harms D, Schmidt D, Ritter J, Keim M, Riehm H, et al. Soft tissue sarcomas in infants younger than 1 year of age: a report of the German Soft Tissue Sarcoma Study Group (CWS81). Med Pediatr Oncol. 1989;17(2):105-10.

7. Spunt SL, Pappo AS. Childhood nonrhabdomyosarcoma soft tissue sarcomas are not adult-type tumors. J Clin Oncol. 2006;24(12):1958-9.

8. Parham DM, Webber BL, Jenkins J3, Cantor AB, Maurer HM. Nonrhabdomyosarcomatous soft tissue sarcomas of childhood: formulation of a simplified system for grading. Mod Pathol. 1995;8(7):705-10.

9. Coffin CM, Fletcher JA. Infantile fibrosarcoma. In: Fletcher CDM, Unni KK, Mertens F. (Eds). WHO Classification of tumors of soft tissue and bone. Lyon IARC Press; 2002.

10. Gebauer CHR. The Postoperative Prognosis of Primary Pulmonary Sarcomas.A Review with a Comparison between the Histological Forms and the Other Primary Endothoracal Sarcomas Based on 474 Cases. Scandin Cardiovas J. 1982;16(1):91-7.

11. Coffin CM. Fibroblastic-myofibroblastic tumors. In: Coffin CM,
Dehner LP, O'Shea PA. (Eds). Pediatric Soft Tissue Tumors: A Clinical, Pathological, and Therapeutic Appraoch. Baltimore, MD. Williams \& Wilkins; 1997.

12. Fisher C. Fibromatosis and fibrosarconia in infancy and childhood. European J Cancer. 1996;32(12):2094-100.

13. Soule EH, Pritchard DJ. Fibrosarcoma in infants and children.A review of 110 cases. Cancer. 1977;40(4):1711-21.

14. Balsaver AM, Butler JJ, Martin RG. Congenital fibrosarcoma. Cancer. 1967;20(10):1607-16.

15. Stout AP. Fibrosarcoma in infants and children. Cancer. 1962;15(5):1028-40.

16. Mackenzie DH. Fibroma: A dangerous diagnosis. A review of 205 cases of fibrosarcoma of soft tissues. British J Surgery. 1964;51(8):607-12.

17. Chung EB, Enzinger FM. Infantile fibrosarcoma. Cancer. 1976;38(2):729-39.

18. Weiss SW, Goldblum JR, Enzinger FM. Enzinger and Weiss's Soft Tissue Tumors. Philadelphia: Mosby; 2008.

19. Enid G. In: Potter's Pathology of the fetus Infant and Child. 2, editor. New York: Mosby-Elsevier; 2007.

20. Sheng WQ, Hisaoka M, Okamoto S, Tanaka A, Meis-Kindblom JM, Kindblom LG, et al. Congenital-infantile fibrosarcoma. A clinicopathologic study of 10 cases and molecular detection of the ETV6-NTRK3 fusion transcripts using paraffin-embedded tissues. Am J Clin Pathol. 2001;115(3):348-55.

21. Bourgeois JM, Knezevich SR, Mathers JA, Sorensen PHB. Molecular Detection of the ETV6-NTRK3 Gene Fusion Differentiates Congenital Fibrosarcoma From Other Childhood Spindle Cell Tumors. Am J Surgic Pathol. 2000;24(7):937-46.

22. Badrawy T, Mansour A, Zalata K. Congenital-infantile fibrosarcoma: evaluation of clinical behaviour and outcome. Egypt $J$ Surg. 2003;22:115-21.

23. Loh ML, Ahn P, Perez-Atayde AR, Gebhardt MC, Shamberger RC, Grier HE. Treatment of infantile fibrosarcoma with chemotherapy and surgery: results from the Dana-Farber Cancer Institute and Children's Hospital, Boston. J Pediatr Hematol Oncol. 2002;24(9):722-6.

24. Orbach D, Rey A, Cecchetto G, Oberlin O, Casanova M, Thebaud E, et al. Infantile fibrosarcoma: management based on the European experience. J Clin Oncol. 2010;28(2):318-23.

25. Kurkchubasche AG, Halvorson EG, Forman EN, Terek RM, Ferguson WS. The role of preoperative chemotherapy in the treatment of infantile fibrosarcoma.J Pediatr Surg. 2000;35(6):880-3.

26. Celkan T, Özkan A, Apak H, İbrahİm B, Dervİşoğlu S, Yüksel L, et al. Two different clinical presentations of infantile fibrosarcoma. Turkish J cancer. 2000;30(2):81-5.

27. Russell H, Hicks MJ, Bertuch AA, Chintagumpala M. Infantile fibrosarcoma: clinical and histologic responses to cytotoxic chemotherapy. Pediatr Blood Cancer. 2009;53(1):23-7.

28. Kupeli S, Akyuz C, Varan A, Gedikoglu G, Yalcin B, Kutluk T, et al. Infantile fibrosarcoma: retrospective analysis of eleven patients. Tumori. 2011;97(2):166-9.

29. Demir HA, Akyuz C, Varan A, Ergen FB, Buyukpamukcu M. Right foot congenital infantile fibrosarcoma treated only with chemotherapy. Pediatr Blood Cancer. 2010;54(4):618-20.

30. Shetty AK, Yu LC, Gardner RV, Warrier RP. Role of chemotherapy in the treatment of infantile fibrosarcoma. Med Pediatric Oncol. 1999;33(4):425-7.

31. Savas C, Candir O, Ozguner F. Acute respiratory distress due to fibrosarcoma of the carina in a child. Pediatr Pulmonol. 2004;38(4):355-7.

32. Picard E, Udassin R, Ramu N, Rosenmann E, Cohen P, Bar-Ziv J, et al. Pulmonary fibrosarcoma in childhood: Fiber-optic bronchoscopic diagnosis and review of the literature. Pediatric Pulmonol. 1999;27(5):347-50.

33. Sahin D, Koc N, Etker S, Guven S, Canpolat C. Congenital pulmonary fibrosarcoma in a newborn with hypoglycemia and respiratory distress: case report. Turk J Pediatr. 2010;52(3):325-9.

34. Pettinato G, Carlos Manivel J, Saldana MJ, Peyser J, Dehner LP. 


\section{Hiradfar A et al.}

Primary bronchopulmonary fibrosarcoma of childhood and adolescence: Reassessment of a low-grade malignancy Clini- copathologic study of five cases and review of the literature. Human Pathology. 1989;20(5):463-71. 